\title{
Correction: The informal curriculum: what do junior doctors learn from a palliative care rotation?
}

Poi $\mathrm{CH}$, Khoo HS, Koh MYH, et al The informal curriculum: what do junior doctors learn from a palliative care rotation? BMJ Support Palliat Care 2020;10:114-17.

In this article, the authors' first names were indicated as their last names. The correct citation is as follows: Poi CH, Khoo HS, Koh MYH, Hum AYM.

(C) Author(s) (or their employer(s)) 2020. No commercial re-use. See rights and permissions. Published by BMJ.

BMJ Supportive \& Palliative Care 2020;0:1. doi:10.1136/bmjspcare-2018-001625corr1

(D) Check for updates 